\title{
TINDAK PIDANA YANG DILAKUKAN OLEH OKNUM SOPIR TAKSI ONLINE MEREKAM VIDEO SEKS DIRINYA DENGAN SEJUMLAH KORBAN UNTUK MEMPEROLEH UANG
}

\author{
Oleh \\ Imam Rahmaddani*)
}

\section{Abstrak}

Kebutuhan masyarakat dalam transportasi online menjadi kebutuhan mendasar saat ini tidak terlepas dari kemudahan mengunakan aplilkasi dalam gengaman tangan dari telpon selular, jumlah jasa penyedia transportasi, dan harga yang sudah ditentukan dari jarak tempuh. Mengunakan aplikasi kendaraan online tidak sulit cukup memiliki meng-install aplikasi transportasi online mengisi identitas diri mulai dari nomor telpon, alamat dan memasukan sejumlah uang kedalam aplikasi tersebut kita bisa langsung melakukan pemesanan kendaraan yang dituju dengan memilih tujuan dan membayar dengan menggunakan uang secara tunai maupun mengunakan uang yang sudah dimasukkan ke dalam aplikasi penyedia jasa. Komunikasi antar pengguna jasa dan sopir taksi online mengunakan aplikasi yang sudah disediakan hingga percakapan apapun bisa disampaikan melalui hal tersebut, dari kemudahan ini disalahgunakan oknum sopir taksi online untuk melakukan komunikasi berlanjut setelah mengantar penumpang, respon dari penumpang terhadap percakapan setelah mengantar penumpang oleh sopir taksi online menjadi pintu masuk pertama hal yang dilakukan untuk melakukan pertemuan berikutnya dengan maksud tujuan yang lain sehingga hubungan asmara tidak dapat dibendung dengan melakukan perbuatan yang tidak semestinya dilakukan oleh sopir online kepada penumpangnya terjadi tidak hanya satu orang dan banyak korban dari perbuatan tersebut hingga merekam perbuatannya dan dijadikan alat untuk menakut-takuti korban untuk memberikan sejumlah uang dengan maksud tidak akan di sebar luaskan video yang sudah direkam.

\section{Kata Kunci : Hukum Pidana, Fenomena Masyarakat, Korban Penipuan}

\section{A.PENDAHULUAN}

Kebutuhan hidup yang harus dipenuhi oleh setiap orang untuk memenuhi kebutuhan premier, sekunder dan tersier menjadi fokus utama setiap orang harus bekerja dan berusaha sehingga banyak profesi pekerjaan yang menuntut setiap orang untuk menunjukkan kemampuan yang dimiliki dilihat dari gelar akademik untuk menentukan tempat yang tepat bagi pelamar pekerjaan untuk diterima sebagai karyawan, serangkaian test tidak

*) Penulis adalah Dosen Fakultas Hukum

Universitas Islam Syekh Yusuf luput dilewati demi lolos pekerjaan tersebut mulai dari test potensi akademik, test keahlian bidang yang dilamar dengan harapan mampu mengerjakan tugas pekerjaan dengan baik sesuai dengan ilmu yang telah diperoleh dalam jenjang pendidikan formal, serangkaian test kepribadian untuk bekerjasama dalam tim untuk memecahkan masalah yang diberikan perusahaan dalam forum diskusi antar pelamar satu dengan yang lain akan diberi sejumlah point untuk dipilih hal mana yang menjadi topik permasalahan yang akan diangkat dalam 
diskusi dan test kesehatan mulai dari paru-paru, jantung, darah, THT demi tercipta pekerja yang sehat dan prima siap untuk ditempatkan dimana saja perusahaan akan menempatkan posisi yang dibutuhkan dalam perusahaan. Dari serangkaian test yang dilakukan menjadi sulit bagi orang yang tidak masuk dalam kriteria hal tersebut maka hal yang paling banyak di profesi yang diambil saat ini adalah sopir taksi online bagaimana langkah yang harus di ambil untuk menjadi sopir online tidaklah mudah harus memiliki kendaraan dengan batas waktu tahun tertentu tidak kurang dari 5 (lima) tahun untuk dijadikan kendaraan sebagai operasional dalam menjalankan profesi sebagai taksi online, mendaftar pada pemilik aplikasi taksi online setelah memiliki kendaraan sendiri juga harus memiliki asuransi kendaraan dan memberikan dokumen kendaraan yang sah dan surat izin mengemudi yang masih berlaku serta dokumen pribadi seperti Kartu Tanda Penduduk dan Kartu Keluarga dan lain-lain dengan tujuan pekerja profesi taksi online dapat terdata oleh penyedia apliksi dan didata oleh Kementerian Perhubungan. Seiring berjalannya waktu taksi online di Indonesia sudah cukup banyak sehingga dapat memilih aplikasi apa yang cocok bagi para pengguna untuk mengunakan aplikasi tersebut, profesi ini sudah menjadi mata pencarian bagi sopir karna pendapatan akan banyak bila bekerja sesuai target yang ditentukan oleh penyedia aplikasi ada tambahan yang akan diterima bila memenuhi target tersebut dapat kita ketahui namanya insentif bagi sopir taksi online dan apapun pekerjaan yang dijalani dengan baik dan tekun akan menghasilkan keuntungan harus terus berjalan dengan mencari sumber rezeki lainnya.

Dalam kehidupan bermasyarakat banyak hal yang terjadi di luar nalar dan akal pikiran manusia niat dari seseorang untuk mengantar jemput penumpang yang menjadi tugas bagi profesi sopir online adalah hal yang mulia selain mendapatkan upah yang diberikan oleh penumpang akan memperoleh uang tambahan dari penumpang ketika dia melakukan pelayanan yang baik bagi penumpang untuk memperoleh tambahan seperti tip sehingga pekerjaan menjadi menyenangkan dan dianggap penting diperoleh untuk menutupi kekurangan operasional kendaraan yang timbul dari kendaraan yang digunakan. Semua orang yang telah mengunakan jasa taksi online merasa puas atas pelayanan yang diberikan penyedia jasa taksi online dapat menentukan arah yang dituju dengan titik koordinat yang diberikan akan menunjukan tempat dimana akan dijemput oleh sopir dan diantar dari hal ini disalahgunakan oleh oknum sopir yang niatnya menggoda dengan menanyakan yang dianggap kondisi pribadi, status pekerjaan, status pernikahan dan lain-lain yang mungkin saja terjadi karena adanya respon positif dari penumpang dengan membalas percakapan tersebut diluar dari konteks pekerjaannya setelah mengantar penumpangnya.

Dari kasus yang terjadi pada berita yang sedang menjadi perbincangan oknum sopir taksi online berinisial AS kerap mengancam penumpangnya dengan video seks yang ia rekam. AS kerap merekam kegiatan hubungan badan yang ia lakukan dengan penumpangnya tanpa sepengetahuan mereka. Selama setahun bekerja sebagai sopir taksi online, setidaknya ada 14 penumpang yang diajak AS berhubungan badan dan direkamnya secara diam-diam. "Si korban ini kaget, ternyata dia yang sedang melakukan hubungan suami istri direkam tanpa sepengetahuannya," kata Kapolsek Kembangan Kompol Joko Handono di kantornya, Jumat (20/12/2019). Video seks itu ia gunakan untuk memeras para korban dengan ancaman akan menjual 
hasil rekamannya tersebut ke situs web lokal. Berdasarkan pengakuan AS, sudah ada dua wanita yang ia peras dengan menggunakan video seks tersebut. Baca juga: Sebelum Viral, Terdakwa Kasus Video Seks Garut Pernah Lapor Polisi Kedua wanita tersebut merupakan penumpang yang dihamili AS hingga akhirnya dinikahi siri olehnya. "(AS) diminta pertanggungjawaban. Minta dinikahkan siri, kemudian diminta menikah secara resmi, tapi tak kunjung dinikahi," ujar Joko. Adapun AS ditangkap setelah salah satu korbannya yang tak tahan terus diperas tersangka. AS diamankan pada Jumat (13/12/2019) lalu, di rumahnya di kawasan Tomang, Jakarta Barat. ${ }^{1}$

Dari permasalahan yang ada maka penulis merumuskan masalah sebagai berikut:

1. Bagaimana faktor pendorong pelaku melakukan perbuatan tersebut?

2. Bagaimana kebijakan kriminal terhadap fenomena yang terjadi atas perbuatan pelaku?

\section{B. PEMBAHASAN}

\section{Bagaimana faktor pendorong pelaku melakukan perbuatan tersebut}

Perbuatan yang dilakukan AS sebagai tersangka dalam hal ini sungguh ironis dengan banyak yang menjadi korban dengan mudahnya diperdaya dengan ajakan mau melakukan hubungan badan yang tidak semestinya dilakukan oleh orang yang baru dikenal dan tidak pernah melangsungkan pernikahan sebelum terjadinya hubungan badan dan merekam adegan yang dilakukan olehnya untuk memperoleh keuntungan dari korban

1 Jimmy Ramadhan Azhar. 2019. Sopir Online Ini Peras Penumpang Dengan Rekaman Video Seks Mereka. Kompas.com [Internet]. [diunduh 2010 Des 28]; http.megapolitan.kompas.com/resd/2019/ $12 / 20 / 18372221$. untuk dijadikan bahan pengancaman agar memberikan sejumlah uang sehingga mau menuruti kemauan tersangka AS memberikan sejumlah uang, kejadian ini bisa muncul kepermukaan hingga menjadi bahan pebincangan dibmasyarakat karena ada korban yang tidak senang atas perlakuan tersangka hingga melaporkan kepolisian, apa yang terlintas dalam pikiran tersangka AS berani melakukan hal tersebut karena di luar batas kewajaran bagaimana tidak dari perbuatannya sudah ada beberapa korban yang hamil dan meminta pertanggungjawaban atas perbuatanya dan mengambil langkah menikah secara siri dan ketika korban meminta pelaku untuk dinikahi secara sah tidak bersedia. Pelaku seorang sopir taksi online yang biasa sehari-hari dengan jumlah orang yang menggunakan jasa transportasi dia pastinya banyak dan banyak orang yang sudah diganggu oleh perbuatan tersangka.

Mens rea merupakan unsur mental dalam perkara pidana, berarti niat jahat untuk melakukan tindak pidana, sukar untuk dibuktikan atas niat apa yang diinginkan tersangka inisial AS kepada korbannya hanya Tuhan Yang Maha Mengetahui. Tersangka dengan maksud mengirim pesan singkat dengan harapan dapat melakukan hal yang sesuai keinginannya dengan menggangu korbannya dengan berkenalan lebih lanjut hingga memiliki status pacaran dengan status baru memudahkan tersangka sering bertemu dan pertemuan tersebut mengajak ketemu jika dianggap sudah ada respon baik dari korban dan mengajak bertemu di suatu tempat hingga membuat rasa nyaman pada korban status dari komunikasi berubah menjadi memiliki hubungan asmara antara keduanya hingga melakukan hubungan badan.

Actus Reus menyangkut perbuatan yang melawan hukum, segala perbuatan yang bertentangan dengan aturan yang 
sudah ada seperti dilakukan oleh tersangka untuk merekam adegan berhubungan badan tanpa diketahui korban dengan maksud memeras korban dengan niat dengan tersebut akan dikirim ke situs porno lokal dan menipu korban-korban tentang perbuatannya memperdaya korban dengan serangkai kebohongan yang dibangun untuk memberikan sejumlah uang. Dalam hal ini tersangka SA melanggar Undang-Undang ITE Pasal 27 Ayat 12 dan Pasal 4 Ayat 1 Undang-Undang Nomor 19 Tahun 2016. ${ }^{3}$

"Setiap Orang dengan sengaja dan tanpa hak mendistribusikan dan/ atau mentransmisikan dan/atau membuat dapat diaksesnya Informasi Elektronik dan/atau Dokumen Elektronik yang memiliki muatan yang melanggar kesusilaan" dengan ancaman pidana paling lama 6 (enam) tahun dan/denda paling banyak Rp. 1.000.000.000,00 (satu miliar rupiah)".

Dan juga dikenakan Pasal 378 KUHP berbunyi sebagai berikut:

"Barang siapa dengan maksud menguntungkan diri sendiri atau orang lain secara melawan hukum, dengan memakai nama palsu atau martabat palsu, dengan tipu muslihat, ataupun rangkaian kebohongan, menggerakkan orang lain untuk menyerahkan barang sesuatu kepadanya, atau supaya memberikan utang maupun

2 Pemerintah Indonesia. 2008. UndangUndang No. 11 Tahun 2008 Yang Mengatur Tentang Informasi Serta Transaksi Elektronik, atau Teknologi Informasi. Lembaran Negara RI Tahun 2008, No. 115. Sekretariat Negara. Jakarta.

3 Pemerintah Indonesia. 2016. UndangUndang No. 19 Tahun 2016 Yang Mengatur Tentang Informasi Serta Transaksi Elektronik, atau Teknologi Informasi. Lembaran Negara RI Tahun 2016, No. 251. Sekretariat Negara. Jakarta. menghapus piutang, diancam karena penipuan dengan pidana penjara paling lama 4 (empat) tahun". ${ }^{4}$

Bahwa faktor yang melatarbelakangi tersangka melakukan hal tersebut dapat kita lihat dari:

1. Faktor Internal

a. Faktor Pendidikan

Faktor pendidikan menjadi salah satu faktor pendorong seseorang untuk melakukan suatu tindak tanpa difikir panjang baik dan buruk dari perbuatan yang dilakukan dapat membawa bencana bagi dirinya bila tertangkap oleh pihak berwajib. Hal itu disebabkan oleh tingkat pengetahuan mereka yang kurang terhadap hal-hal seperti aturan yang dalam cara hidup bermasyarakat. "tingkat pendidikan dianggap sebagai salah satu faktor yang mempengaruhi seseorang berbuat jahat dan nekad untuk merekam adegan hubungan badan antara tersangka dan korban, pendidikan merupakan sarana bagi seseorang untuk mengetahui mana yang baik dan mana yang buruk dan dengan melakukan suatu perbuatan apakah perbuatan tersebut memiliki suatu manfaat tertentu atau malah membuat masalah/kerugian tertentu.

b. Faktor Individu

Seseorang yang tingkah lakunya baik dan buruk akan mengakibatkan seseorang tersebut mendapatkan pengakuan baik dari lingkungan sekitar sehingga pergaulan dalam masyarakat akan menjadi menyenangkan akan malu untuk berbuat tidak baik hal itu dapat dihindari dari tingkatan lapisan paling bawah, akan tetapi sebaliknya jika seseorang bertingkah laku tidak baik maka orang itu akan menimbulkan cemooh bahkan ejekan dalam masyarakat dan pengucilan

${ }^{4}$ Kitab Undang-Undang Hukum Pidana (KUHP). Sinar Grafika. Jakarta. 
terhadap seseorang yang telah melakukan perbuatan tercela tidak diterima lagi oleh masyarkat berdampak pada depresi tingkat tinggi hingga tidak ada yang mau berbaur dengannya. Mereka yang dapat mengontrol dan mengembangkan kepribadiannya yang positif bergaul baik dengan lingkungan dan turut serta dalam kegiatan kemasyarakatan akan dapat menghasilkan banyak manfaat baik itu bagi dirinya sendiri maupun bagi orang lain. Sedangkan mereka yang tidak bisa mengontrol kepribadiannya dan cenderung terombangambing oleh perkembangan jaman yang kian mengerikan dan tidak memberikan rasa aman dan kenyamanan bagi batin yang terus melakukan hal-hal yang tidak baik kemungkinan terbiasa dengan hal itu sudah dianggap hal yang biasa dan menjadi rutinitas untuk melakukan hal negatif tersebut. Entah itu baik atau buruk mereka akan tetap mengikuti hal tersebut. Terdapat pula penyebab seseorang melakukan tindak pidana, seperti yang telah disebutkan di atas bahwa keinginan manusia merupakan hal yang tidak pernah ada batasnya.

2. Faktor Ekstern

a. Faktor Ekonomi

Kemiskinan menjadi sebuah fenomena yang sulit untuk ditekan pada setiap negara-negara. Hingga sekarang banyak cara yang sudah dikerjakan pemerintah untuk menyelesaikan permasalahan ini mulai dari pemberian jenis kartu-kartu yang menjadi handalan pemerintahan saat ini. belum ada langkah yang signifikan pada segi ekonomi dan pemberian pelatihan kepada orang tersebut untuk melakukan pengembangan diri terhadap tantangan global saat ini. Plato mengemukakan bahwa di setiap negara dimana banyak terdapat orang miskin, dengan secara diam-diam terdapat banyak penjahat, pelanggar agama dan dan penjahat dari bermacam-macam corak Hampir setiap tahun harga kebutuhan pokok terus meningkat, sedangkan pendapatan tiap individu belum tentu mampu untuk mencukupi peningkatan tersebut.

b. Faktor Lingkungan

Selain faktor ekonomi, faktor lingkungan menjadi salah satu faktor yang memiliki pengaruh atas terjadinya perekaman video dengan harapan dapat memeras harta korban dengan mengancam akan menyebar video yang sudah direkam secara diamdiam oleh pelaku. Seseorang yang hidup/tinggal di dalam lingkungan yang penuh dengan tuntutan gaya hidup dapat menjadi pendorong yang kuat untuk melakukan hal tersebut karna tidak mampunya seorang untuk mengatur keuangan dan besaran yang diperoleh dari uang yang didapat mengakibatkan besarnya pengeluaran menimbulkan kekurangan terus menerus sehinga nekat melakukan hal tersebut. Maka di suatu waktu ia juga akan melakukan itu menjadi keharusan banyak hal yang membuat lingkungan menjadi faktor penyebab terjadi tersebut. Misalnya kebutuhan dalam pergaulan dengan teman sebaya, kontrol dari lingkungan yang kurang dan pergaulan dengan seseorang yang hanya menampilkan keindahan apa yang ada dalam dirinya tidak pernah ada yang menanyakan uang yang diperoleh dari mana sehingga mampu melakukan di luas batas kemampuan demi ada pengakuan atau di anggap orang kaya.

c. Faktor Penegakkan Hukum Harus ada hukuman yang dijatuhkan pada kasus seperti ini karena banyak pasal yang dapat dikenakan terhadap tersangka atas perbuatan yang 
dilakukan tersangka AS menipu banyak korban dan tidak segan-segan mengajak berhubungan badan sehingga dari beberapa korban hamil dan meminta pertanggungjawaban atas kelakuannya, sehingga memberi efek yang jera untuk pengikutnya yang ingin melakukan perbuatan yang sama seperti pelaku ini.

d. Faktor Perkembangan Global

Perkembangan global memiliki dampak yang positif bagi kemajuan suatu negara, sedangkan bagi individu perkembangan global merupakan suatu sarana untuk menunjukan bahwa dia adalah seseorang yang mampu memenuhi kebutuhan hidupnya dalam masa perkembangan global tersebut. Selain itu seseorang yang memiliki sesuatu (harta) yang lebih dipandang sebagai orang yang sukses, hal ini tentunya membuat setiap orang dalam masyarakat bersaing satu sama lainnya untuk menunjukkan bahwa dirinyalah yang paling unggul. Dan tidak dapat dipungkiri bahwa orang yang tadinya kurang mampupun akan ikut bersaing meskipun mengunakan cara-cara yang salah. Kebanyakan dari mereka lebih memilih cara yang praktis daripada harus bekerja lebih keras tanpa memikirkan resiko apa yang akan diterimanya kelak atas perbuatan yang telah ia lakukan. Seperti halnya salah satunya pelaku tersebut melakukan hal yang telah merugikan koban bagi korbannya.

Faktor lain yang perlu menjadi fokus dalam permasalahan ini terhadap pelaku yang telah berhubungan badan lebih dari satu orang didapat informasi dari pihak kepolisian yang telah melakukan pengembangan kasus ini dengan tidak hanya dari pengakuan tersangka namun pihak kepolisian juga melakukan pengecekan kepada handphone pelaku dan didapatkan hasil bawah ada 14 (empat belas) video yang merupakan semua korban dari hubungan asmara yang ditebarkan kepada korbankorbannya, dalam video yang sudah direkam secara diam-diam oleh tersangka dijadikan alat untuk meminta sejumlah uang agar tidak disebarkan luas isi video tersebut hal ini menimbulkan kekhawatiran, penerbitan pedoman tingginya angka HIV/AIDS dan penyakit menular seksual baik di dunia dan di Indonesia menjadi masalah global. 5 Resiko penularan infeksi menular seksual ini perlu didasarkan oleh perilaku dari tersangka yang sudah melakukan hubungan badan lebih dari sekali tidak hanya pada satu pasangan. Anjuran yang tepat bagi korban yang telah menjadi kejahatan dari tersangka dapat melakukan pemeriksaan HIV/AIDS. Sekiranya penting dilakukan kesehatan kepada korban terserbut akan memberikan rasa aman atas apa yang sudah dialami oleh korban menjadi perhatian pemerintah untuk membantu dari dinas-dinas terkait seperti dinas kesehatan yang memberikan pemeriksaan terhadap masalah yang dialami oleh korban bagi korban yang sedang mengandung dapat diperhatikan untuk proses kelahirannya sehingga baik yang ada dalam kandungan menjadi terjaga akan kesehatannya bahwa negara menjamin proses kelahirannya hingga bayi dapat lahir dengan sehat, setelah anak yang lahir dapat diberikan kemudahan untuk mencantumkan nama. Perlindungan hukum kepada korban tidak ada intimidasi dari pihak manapun untuk memberikan keterangan yang sebenarbenarnya guna kepentingan penyidikan dan penyelidikan sehingga tidak proses perkembangan kasus yang dialami

5 Profil kesehatan Indonesia. Kementrian Kesehatan RI. Jakarta: 2015. [internet] [cited 2017 Sep 04]. Available from: http://www.depkes.go.id/resources / download/pusdatin/profil-kesehatanindonesia/profil-kesehatan-Indonesia-2015. 
korban dapat diproses sebagaimana semestinya dengan aturan hukum yang berlaku dengan membuat effek jera bagi pelaku yang lain takut untuk melakukan perbuatan yang sama kepada korbankorban lainnya.

\section{Bagaimana kebijakan kriminal ter- hadap fenomena yang terjadi atas perbuatan pelakunya}

Negara Indonesia merupakan negara hukum yang mengatur setiap perorangan yang melakukan perbuatan melanggar aturan umum masuk sudah diatur dalam undang-undang dapat dipastikan akan dikenakan sanksi bagi pelanggarnya maka dari itu pemerintah Indonesia terus berkomitmen memberikan rasa aman bagi setiap warga negaranya yang akan melakukan aktifitas di Indonesia dan tanpa terkecuali bagi warga negara asing tunduk pada aturan di Indonesia sesuai perjanjian antar Negara, segala perbuatan yang dilakukan oleh siapapun akan di tindak dengan ketentuan peraturan yang berlaku berdasarkan kebijakanya nya. Kebijakan adalah rangkaian konsep dan asas yang menjadi pedoman dan dasar rencana dalam pelaksanaan suatu pekerjaan, kepemimpinan, dan cara bertindak. Tujuan dan harapan dari sebuah kebijakan di harapkan membawa kearah yang lebih baik dan menjadi penunjang bagi peraturan-peraturan yang sudah udah demi terciptaknya sinergi yang baik antara satu sama lain dengan segala kepentingan dari permasalahan yang ada tetap menjadi perhatian khususnya penyelenggara negara yang mempermudah proses pelaporan bagi korban kejahatan dengan tidak hanya datang ke kantor polisi melainkan dengan cara lain cukup dengan telpon menyebutkan indentitas kartu tanda penduduk dapat menjelaskan kronologis permasalahan yang terjadi dengan diproses melalui komputerisasi tersebut setiap pergerakan sebuah tindak pidana yang dilakukan cepat memperoleh respon dari instansi pemerintah sehingga Ius constitutum dan Ius Constituendum dari sebuah negara dapat berjalan dengan semestinya.

Dengan diterapkan pada pemerintah organisasi dan kelompok sektor swasta, serta individu Kebijakan berbeda dengan peraturan dan hukum. Jika hukum dapat memaksakan atau melarang suatu perilaku (misalnya suatu hukum yang mengharuskan pembayaran pajak penghasilan), kebijakan hanya menjadi pedoman tindakan yang paling mungkin memperoleh hasil yang diinginkan. Hasil dari sebuah kebijakan yang diharapkan oleh masyarakat dapat dirasakan langsung dengan secepat-cepatnya dengan adanya kebijakan tersebut dapat dilihat dari kasus yang dilakukan oleh Tersangka AS atas perbuatan yang dilakukan oleh sopir online masuk ke dalam tindak pidana dengan mengunakan aplikasi dalam profesi sopir online berkomunikasi dua arah antar pemesan jasa transportasi dengan sopir taksi online sehingga ada masalah yang timbul dari oknum menyalahgunakan aplikasi yang dibuat oleh penyedia jasa aplikasi. Dengan demikian kejahatan berkembang seiring dengan kemajuan peradaban sebuah bangsa. ${ }^{6}$ Bangsa yang maju akan terus memajukan masyarakatnya dengan perkembangan teknologi globalisasi seiring dengan percepatan jaman dibutuhkan terobosan regulasi yang mengikuti peradaban dan tingkah laku manusia antara sesama mahluk hidup dalam kehidupan sehari-hari banyak sekali ragam permasalahan karena keinginan untuk memiliki uang yang banyak dalam waktu singkat masih menjadi idaman setiap orang mengunakan cara-cara yang tidak baik dengan mencari celah melakukan penipuan yang dilakukan sopir taksi online ini dan kebutuhan lain juga ikut

6 M. Ali Zaidan, Kebijakan Kriminal, Sinar Grafika, Jakarta, 2016. 
mendorong seseorang melakukan perbuatan yang dapat melanggar hukum sehingga memakan korban dari perbuatan tersebut sehinngga timbul permasalahan yang perlu dibenahi dan menjadi tugas pemerintah membuat terobosan bagaiamana sebuah perbuatan yang merugikan bagi orang atau korban tidak ada lagi yang berjatuhan.

Saat ini juga membutuhkan sebuah kebijakan kriminal atau penanggulangan kejahatan pada hakekatnya merupakan bagian integral dari upaya perlindungan masyarakat (social defence) dan upaya mencapai kesejahteraan masyarakat (social welfare) oleh karena itu dapat dikatakan bahwa tujuan akhir atau tujuan utama dari politik kriminal adalah perlindungan masyarakat untuk mencapai kesejahteraan masyarakat.

Sudarto pernah mengemukakan tiga arti mengenai kebijakan kriminal, yaitu: ${ }^{7}$

1. Dalam arti sempit, ialah keseluruhan asas dan metode yang menjadi dasar dari reaksi terhadap pelanggaran hukum yang berupa pidana;

Asas-asas yang sudah ada harus menjadi pedoman bagi setiap warga negara dengan diterpakan nilainya dalam kehidupan sehari-hari dengan diterapkan sejak diri melalui kebijakan dari pemerintah bahkan dalam dunia pendidikan perlu ditanamkan hal tersebut sehingga menjadi suatu hal yang biasa karena berjalan dalam kehidupan sehari-hari dan menjadi biasa, cukup berjalan dengan baik tetapi masih ada yang kurang mengerti bagai mana mengimplementasikan dari setiap perbuatan yang terkandung dalam kehidupan sehari-hari berjalan sesuai dengan asas yang berlaku serta metode yang tepat dalam menentukan undang-undang yang di

7 Barda Nawawi Arief, 2008, Bunga Rampai Kebijakan Hukum Pidana (Perkembangan Penyusunan Konsep KUHP Baru), Kencana Prenada Media Group, Jakarta, hlm. 1 kenakan pada kasus sopir online yang melakukan perbuatan tidak hal yang biasa dan banyak yang menjadi korban karena tersangka mengerti dalam menggunakan aplikasi tersebut pada akhirnya mencari ruang untuk melakukan tindak pidana kriminal bahwa undang-undang Informasi dan Transaksi Elektronik tepat dikenakan kepada tersangka AS karena masuk dalam unsur-unsur yang ada dalam Pasal 27 ayat 1 begitu pula perlu dijatuhi sanksi dan peraturan yang lain di dalam pasal Kitab Undang-undang Hukum Pidana sudah harus dikenakan kepada tersangka dengan berjalan dengan semestinya regulasi yang dibuat untuk memperlihatkan bahwa negara selalu hadir pada setiap warga negara yang dirugikan demi terciptanya keamanan dan kenyaman dalam hidup bermasyarakat di Indonesia.

2. Dalam arti luas, ialah keseluruhan fungsi dari aparatur penegak hukum, termasuk di dalamnya cara kerja dari pengadilan dan polisi ;

Mulai dari tingkat Kepolisian dalam menangani Kasus ini meminta keterangan kepada seluruh korban menjadi hal yang wajib untuk memastikan bahwa tidak ada serangkaian peristiwa hukum yang terputus untuk menarik kesimpulan sehingga dalam pelimpahan berkas tidak adanya pengembalian dari tingkat kejaksaan untuk menuntut sebuah tindak pidana yang dan pasal yang disangkakan oleh penuntut umum tepat dan tidak memberi ruang pada tersang untuk menyanggah dari tuntutan yang akan dibuat oleh penuntut umum kemudian hakim yang mendegarkan semua kesaksian yang dihadirkan serta menghadirkan saksi ahli jika dibutuhkan untuk menerangkan sebuah kasus pidana sehingga serangkaian persidangan menjadi hal yang patut dijalakan dengan baik dan mendengarkan keterangan terdakwa AS nantinya untuk menjelaskan atas perbuatan yang sudah ia lakukan kepada korban-korbannya dari 
serangkaian Kitab Hukum Acara Pidana (KUHAP) sudah berjalan dengan baik majelis hakim dapat menarik kesimpulan yang tepat dan berimbang untuk menjatuhkan sanksi yang tepat nantinya kepada terdawa tersebut.

3. Dalam arti yang paling luas, ialah keseluruhan kebijakan yang dilakukan melalui perundang-undangan dan badan-badan resmi, yang bertujuan untuk menegakkan normanorma sentral dari masyarakat.

Hakim diharapkan menjatuhkan hukuman sesuai dengan aturan yang ada pada peraturan dengan melihat dari sisi kemanusian bahwa ada korban yang teraniaya atas perbuatan yang dilakukan oleh Tersangka AS, selain peran Majelis Hakim dari luar Pengadilan ada yang perlu didorong untuk pencegahan sebelum terjadinya perbuatan tersebut terjadi adalah peran dari Masyarakat menjadi hal yang turut andil menurunkan tingkat kejahatan bahkan tidak ada lagi permasalahan ini akan terjadi. Dalam kasus ini koperatifnya memberikan informasi yang seluas-luasnya tentang apa yang dijadikan kebutuhan bagi aparat hukum untuk membatu menyelesaikan permasalahan ini dan juga bagi para korban mendapat perhatian dari tokoh masyarakat yang mengetahui permasalahan ini. Dalam sisi lain harapan kepada aparatur desa atau tokoh masyarakat di sekitar rumah korban dapat membatu proses pemulihan dan pengembalian kepercayaan diri bagi korban terhadap permasalahan yang terjadi bukan akhir dari semuanya bahwa korban merupakan masyarakat seperti orang yang biasa butuh bantuan dan pertolongan pembuatan Akte Kelahiran bagi bayi yang dilahirkan dari korban pada instansi pemerintahan pencatatan kependudukan setelah anak yang dilahirkan oleh korban dan nantinya anak tersebut yang dapat diterima dalam kehidupan bermasyarakat sama seperti yang lain, hal yang tidak kalah penting bagi masyarakat sekitar rumah Tersangka Rukun Tetangga dan Rukun Warga diharapkan turut serta memberikan pelajaran yang baik dan dapat merangkul pelaku yang telah selesai menjalankan masa hukuman dalam penjara dan membantu pelaku untuk tidak melakukan kembali perbuatan tersebut dengan melakukan komunikasi yang baik antar sesama anggota masyarakat.

Sudarto mengemukakan defenisi singkat, bahwa kebijakan kriminal adalah merupakan suatu usaha yang rasional dari masyarakat dalam menanggulangi kejahatan atau selanjutnya dikatakan bahwa kebijakan penanggulangan kejahatan merupakan ilmu untuk menanggulangi kejahatan. ${ }^{8}$

\section{PENUTUP}

\section{Kesimpulan}

Memperhatikan kasus diatas dapat di tarik kesimpulan dari seluruh pembahasan dalam seluruh penulisan ini dapat ditarik kesimpulan, yaitu sebagai berikut:

Ada Faktor-faktor penyebab terjadinya banyak korban yang terkena dengan modus rayuan pelaku melalui sarana komunikasi yang diperuntukkan untuk pengguna jasa taksi online dengan sopir taksi online. Cara memperoleh uang tidak baik dengan memeras uang korban melalui video yang sebelumnya telah direkam tanpa sepengetahuan korbannya pastinya uang yang diperoleh untuk membutuhi kebutuhan hidup sehari-hari sehingga terjadinya perbuatan yang bertentangan degan hukum timbul masalah dan keresahan di dalam masyarakat adalah faktor ekonomi, lingkungan, pendidikan dan efek jera dalam penjatuhan sanksi, faktor-faktor tersebut saling berinteraksi dan saling mempengaruhi antar

8 Ibid 
satu dengan yang lainnya. Upaya-upaya yang dilakukan dalam meminimalisir terjadinya kejahatan seperti ini harus ada batasan bagi pengguna aplikasi sebatas sebagai pengguna jangan mudah dirayu oleh orang yang mempunyai niat jahat dan berikutnya adalah upaya preventif dan upaya represif. Upaya preventif dilakukan untuk pencegahan pada masyarakat peka harus peka terhadap perbuatan yang boleh dilakukan dan tidak dilakukan sesuai dengan aturan yang berlaku. Sedangkan upaya represif yang merupakan upaya penindakan berupa penangkapan untuk selanjutnya diproses secara hukum terhadap pelaku kejahatan tersebut dengan hukuman yang setimpal atas perbuatan yang telah dilakukan tersangka berinisial SA.

\section{Saran}

Untuk terulang terjadinya masalah yang menimpa korban dari perbuatan tersangka AS perlunya regulasi bagi penyedia Aplikasi dengan melakukan kontrol yang tepat guna bagi sopir taksi online yang telah menyelesaikan tugasnya tidak diberikan akses komunikasi kembali pada pelanggan yang membuat ruang komunikasi itu akan terjalin, membuat ruang pengaduan bagi pengguna taksi online untuk melaporkan hal-hal yang mencurigakan bagi sopir sopir online yang dianggap tidak menjalankan aturan yang telah dibuat.

Ruang leluasa pada Instansi kepolisian untuk memperoleh data dari sopir-sopir yang mendapat pengaduan dari pelanggan taksi online bahkan harus ada pelatihan yang diberikan kepada sopir dan berjalan dengan berkesinambungan dengan harapan meminimalisir terjadi perbuatan yang tidak seharusnya dilakukan oleh sopir online karena pembekalan diberikan langsung oleh pihak Kepolisan khususnya bidang Korlantas Polri.
Pemberian pemidanaan pada Tersangka AS harus diperhatikan faktor pemberat melihat dari banyaknya jumlah korban bahkan ada 3 (tiga) orang bersama-sama mengandung anak dari hubungan terlarang mengakibatkan keguncangan jiwa yang dialami oleh korban dari tersangka dapat dirasakan begitu berat terlebih Tersangka tidak dapat mempertanggungjawabkan perbuatan dan tidak memiliki uang yang cukup untuk membantu biaya yang akan dikeluarkan proses persalinan dan juga menjadi efek jera bagi laki-laki yang akan mengikuti jejak tersangka AS dengan penjatuhan yang berat.

\section{DAFTAR PUSTAKA}

Jimmy Ramadhan Azhar. 2019. Sopir Online Ini Peras Penumpang Dengan Rekaman Video Seks Mereka. Kompas.com [Internet]. [diunduh 2010 Des 28]; http.megapolitan.kompas.com/res d/2019/12/20/18372221.

M. Ali Zaidan, Kebijakan Kriminal, Sinar Grafika, Jakarta, 2016.

Barda Nawawi Arief, 2008, Bunga Rampai Kebijakan Hukum Pidana (Perkembangan Penyusunan Konsep KUHP Baru), Kencana Prenada Media Group, Jakarta, hlm. 1

Profil kesehatan Indonesia. Kementrian Kesehatan RI. Jakarta: 2015. [internet] [cited 2017 Sep 04]. Available from: http://www.depkes.go.id/re sources/download/pusdatin/profi 1-kesehatan-indonesia/profilkesehatan-Indonesia-2015. 
Pemerintah Indonesia. 2008. UndangUndang No. 11 Tahun 2008 Yang Mengatur Tentang Informasi Serta Transaksi Elektronik, atau Teknologi Informasi. Lembaran Negara RI Tahun 2008, No. 115. Sekretariat Negara. Jakarta.

Pemerintah Indonesia. 2016. UndangUndang No. 19 Tahun 2016 Yang Mengatur Tentang Informasi Serta Transaksi Elektronik, atau Teknologi Informasi. Lembaran Negara RI Tahun 2016, No. 251. Sekretariat Negara. Jakarta.

Kitab Undang-Undang Hukum Pidana (KUHP). Sinar Grafika. Jakarta 